\title{
Effect of eating resistant starch on the development of overweight, obesity, and disorders of carbohydrate metabolism in children
}

Wpływ spożywania skrobi opornej na rozwój nadwagi, otyłości i zaburzeń w gospodarce węglowodanowej u dzieci

\author{
${ }^{1}$ Agnieszka Lejk, ${ }^{1}$ Małgorzata Myśliwiec, ${ }^{2}$ Artur Myśliwiec \\ ${ }^{1}$ Department of Paediatrics, Diabetology, and Endocrinology, Medical University of Gdansk, Poland \\ ${ }^{2}$ Department of Sports Physiology, University of Physical Education and Sport in Gdansk, Poland
}

\begin{abstract}
Overweight and obesity in children is becoming an increasingly common problem due to the increased access to processed food, overly high energy density diet, and limitation of physical activity in children. Such trends in today's society lead to health consequences that can be observed in the early stages of carbohydrate metabolism disorders. Reduction of body weight and changes in eating habits can prevent the onset of type 2 diabetes. Recently, the benefits of consuming products containing resistant starch, which has the main advantage of influencing the metabolic pathway of glucose, have been increasingly underlined.

To date, no recommendations have been made for the daily intake of resistant starch or its content in individual products available on the food market. However, in the medical literature, there are an increasing number of reported cases of the beneficial effect of consuming resistant starch as a factor that supports glycaemic control in children with carbohydrate disorders.

Unfortunately, the above topic requires further research in this direction, especially in the developmental age population, which will allow the formulation of precise conclusions regarding its use in the prevention of overweight, obesity, carbohydrate metabolism disorders, and the development of diabetes.
\end{abstract}

Key words:

resistant starch, overweight, obesity, carbohydrate metabolism.

\section{Streszczenie}

Nadwaga i otyłość u dzieci staje się coraz częstszym problemem ze względu na zwiększony dostęp do przetworzonej żywności, zbyt dużą gęstość energetyczną diety oraz ograniczoną aktywność fizyczną u dzieci. Takie trendy dzisiejszego społeczeństwa prowadzą do występowania konsekwencji zdrowotnych, które na samym początku można zaobserwować w zaburzeniach gospodarki węglowodanowej. Redukcja masy ciała oraz zmiana nawyków żywieniowych mogą zapobiec wystąpieniu cukrzycy typu 2. Ostatnio coraz częściej podkreśla się korzyści ze spożywania produktów zawierających skrobię oporną, której główną zaletą jest wpływ na szlak metaboliczny glukozy. Do dnia dzisiejszego nie stworzono zaleceń dotyczących dziennego spożycia skrobi opornej ani nie uwzględniono jej zawartości w poszczególnych produktach dostępnych na rynku spożywczym. Mimo to w literaturze pojawia się coraz więcej doniesień o korzystnym wpływie spożywania skrobi opornej jako czynnika, który wspomaga kontrolę glikemii u dzieci z zaburzeniami gospodarki węglowodanowej. Niestety, powyższa tematyka wymaga dalszych badań w tym kierunku, szczególnie w populacji wieku rozwojowego, które pozwolą na sformułowanie precyzyjnych wniosków dotyczących jej stosowania w profilaktyce nadwagi, otyłości, zaburzeń gospodarki węglowodanowej i rozwoju cukrzycy.

\section{Słowa kluczowe:}

skrobia oporna, nadwaga, otyłość, metabolizm węglowodanów. 


\section{Introduction}

Currently, overweight and obesity in children is becoming an increasingly common problem due to increased access to processed food, overly high energy density of diet compared to energy expenditure, and a sedentary lifestyle [1].

Such trends in today's society lead to the occurrence of health consequences, which can be observed in the beginning of carbohydrate metabolism disorders [2].

Recent studies conducted by HBSC (Health Behaviour in School-aged Children) in 2014, in the population of Polish students, confirmed that overweight and obesity is a problem that affects $14.8 \%$ of children taking part in the study [3].

According to the data collected by the National Health Program in 2014-2018, there was an increase in adolescents with excessive body mass, from $19.9 \%$ to $21.7 \%$. It was noted that the critical age in children is 13 years, and the incidence of the problem is increasing in the group of boys [4].

The observed trend gives an unsatisfactory result, and obesity is a factor strongly predisposing to the development of insulin resistance and type 2 diabetes in children [5]. Increased incidence of type 2 diabetes is observed in paediatric patients aged 12-16, at the time of puberty. It should be remembered that not every child with excessive weight and insulin resistance will develop type 2 diabetes [6]. Body weight reduction as well as change in eating habits can prevent the incidence of type 2 diabetes mellitus. Recently, the benefits of consuming products containing resistant starch, which has the main advantage of affecting the metabolic pathway of glucose, have been increasingly underlined [7].

The purpose of the article is to summarise current reports on the beneficial effect of consuming resistant starch as a factor that supports glycaemic control in children with carbohydrate metabolism disorders.

\section{The impact of diet on reducing the occurrence of metabolic complications}

The first modification in the nutritional habits of children with abnormal body weight and/or carbohydrate and lipid metabolism disorders is the modification of their diet so that it is consistent with the basic principles of proper nutrition.

These include the consumption of products with low and medium glycaemic index [8]. These products are characterised by IG below 55, and they are a rich source of dietary fibre, which has a positive effect on regulating the level of glucose in the blood.

The currently accepted definition of dietary fibre also includes resistant starch, which works compatibly with other non-digested parts of carbohydrates by the human body. Resistant starch is digested by in vitro digestive enzymes over 120 minutes [9].

To this day, no recommendations have been completed for the daily intake of resistant starch or its content in individual products available on the food market. The main reason is its variability, inter alia, due to cooking, cooling, and product maturation [10].

In developing countries, the intake of resistant starch varies between 30-40 g per day and depends on the selection of the group of products in daily nutrition [11].

Resistant starch is categorised into four types:

- RS1 - whole-grain products (e.g. bread, seeds, legumes);

- RS2 - raw potatoes, green bananas, maze with a high amylose content;

- RS3 - boiled and then cooled starchy products such as: potatoes, stale bread, pasta, rice, cereals;

- RS4 - food products based on chemically modified starches, e.g. commercially produced bread or cakes;

- RS5 - food products containing a natural combination of amylose-lipid complex in fat-containing bread as an ingredient or food products containing artificial amylose-lipid complexes such as stearic acid complex of high amylose starch [12].

The Landon publication from 2012 contains selected sources of resistant starch in food products available on the British market. It shows, among other things, how the degree of maturity of a given food product affects the content of resistant starch, for instance, mature banana contains $1.23 \mathrm{~g}$ $\mathrm{RS} / 100 \mathrm{~g}$ of the product, and green banana $8.50 \mathrm{~g} \mathrm{RS} / 100 \mathrm{~g}$.

Attention was also paid to the influence of heat treatment on the content of resistant starch in food products. Dry legume seeds consumed without prior preparation contain $3.4 \mathrm{~g}$ $\mathrm{RS} / 100 \mathrm{~g}$ of product, and after their cooking, the content of resistant starch increases even to the level of $9.1 \mathrm{~g} \mathrm{RS} / 100 \mathrm{~g}$ of product [13].

More and more scientific works show the beneficial effect of consuming products containing resistant starch. This article aims to summarise the most important research in this topic.

\section{Resistant starch and glucose metabolism}

Unfortunately, as of today, most studies on resistant starch have been carried out on adults, and there are few reports of its effect in paediatric patients available in the literature. Previous studies focus on the following types: RS1, RS3, and RS4 and their impact on carbohydrate metabolism, and in particular on the metabolism of glucose and insulin [14].

One of the few studies conducted on the group of obese children was published in 2015 by Ayrana et al. The study involved 110 patients aged 7-8 years and 13-14 years with excessive body mass who for four weeks consumed yogurt enriched with resistant starch. The conclusions from the above study did not show any clear benefits of the influence of resistant starch consumption on the improvement of insulin sensitivity in children [15]. In turn, Bodingham et al. conducted a study on a group of 20 adult patients who received a type 2 resistant starch in a 48-gram dose per day spread over two meals. Increased intake of resistant starch did not affect the level of glucose, but significantly reduced the level of insulin secretion [16]. 
However, another study describing the above topics was published by Poquette et al. It focused on the influence of resistant starch obtained from brown rice. This product was previously subjected to a thermal treatment and then transformed into flour. After observing a group of 14 healthy men, the plasma glucose was reduced by $36 \%$ and insulin by $28 \%$, compared to the control group in which such a nutritional modification was not introduced [17]. Researchers cooperating with Hallstrom, who carried out their research using cereals containing a large amount of amylose, reached somewhat different conclusions. The daily portion of resistant starch served in said food product was $7.7 \mathrm{~g} /$ day. The supply in such a dose of resistant starch allowed for the reduction of glucose and insulin [18].

One of the latest research projects carried out by Stewart et al. showed a significant difference in post-prandial blood glucose concentration and the discharge of insulin from the pancreas under the influence of swapping a food product containing wheat flour into a product with the addition of RS4.

In the study, a significant reduction in the postprandial glucose and insulin levels was observed in the study group after a meal with the addition of RS4 [19].

\section{Resistant starch and intestinal microflora}

It should be noted that resistant starch not only affects the metabolism of glucose in the body, but also has been proven to have beneficial properties on the consumption of the intestinal microflora. It has now been found that the composition on intestinal bacteria differs in patients with normal body mass compared to people who are overweight or obese [20].

One of the most important differences among the obese patients is the increase in bacterial lipopolysaccharide (LPS), the excessive concentration of which results in abnormal glucose and triglyceride metabolism and, consequently, an increased risk of insulin resistance [21].

In 2015, the effect of supplementation with type 2 resistant starch in children aged $3-5$ years was examined. Within four weeks, a group of 18 subjects were supplemented with RS2 supplement in a dose of $8.5 \mathrm{~g}$ per day. The results of the study were not unequivocal and there were no significant changes in the effect of resistant starch on intestinal microflora in children [22].

Studies on the impact of resistant starch on intestinal microflora were also conducted in adult patients in 2017 by a research centre in the USA. It was found that a diet rich in resistant starch positively influences the increase of enzymatic pathways during digestion and the metabolism of lipids in the intestines [23].

\section{Resistant starch and appetite}

The influence of resistant starch on the regulation of appetite and the feeling of satiety is more often observed [24].

Gentile et al., when conducting studies on the obese and overweight group, verified that only meals containing resistant starch in combination with protein accelerated the metabolism of fat and the feeling of satiety [25].

Another report proving that the introduction of products containing resistant starch favourably affects glucose metabolism and appetite regulation is the study by Sandberg et al. carried out on a group of 21 healthy people. A meal containing bread made from rye flour was given to each person involved in the Sandberg study [26]

There are also some reports - including the results of a study conducted by Castillo-Ble et al., who analysed the effect of green banana intake on appetite in healthy people which did not show a correlation between the consumption of resistant starch and its effect on decreased appetite [27].

\section{Conclusions}

To sum up the current knowledge about resistant starch, there is no unambiguous position as to the benefits of its consumption. There are, however, many scientific reports about its beneficial effects on carbohydrate metabolism, the composition of the body's microflora, appetite regulation, and body weight.

Most researchers have adopted a common position regarding its beneficial effects on glucose metabolism. The introduction of an adequate amount of resistant starch into the daily diet reduces the glucose level and the consequent reduction of insulin output.

Other advantages of resistant starch are not fully tested, although there are various opinions about it and its effect on the human body in the literature. Currently, a very popular topic related to the incorrect composition of the intestinal microflora and its effect on the occurrence of the metabolic syndrome is not fully understood [28].

However, more and more scientific reports indicate that abnormal intestinal microflora affects the predisposition to insulin resistance and the development of diabetes [29].

It should be noted that the subject of resistant starch is the least studied in the paediatric group. The subject matter analysed in this article requires further studies and research in this direction, especially in the developmental age population, which will allow the formulation of precise conclusions regarding the use of resistant starch in the prevention of overweight, obesity, carbohydrate metabolism disorders, and the development of diabetes. 


\section{References}

1. Onis M, Blossner M, Borghi E. Global prevalence and trends of overweight and obesity among preschool children. Am J Clin Nutr 2010; 92: 1257-1264. doi: 10.3945/ajcn.2010.29786

2. Stąpor N, Beń-Skowronek I. Insuline resistence in children. Pediatr Endocrinol Diabetes Metab 2014; 20: 107-115. doi: 10.18544/ PEDM-20.03.0010

3. Mazur J. Health and health behaviour of school children in Poland against the background of selected socioeconomic conditions. Findings HBSC 2014. Mother and Child Institute, Warsaw 2015; 2-3.

4. National Program for Prevention of Overweight and Obesity and Chronic Non-infectious Diseases by Improving Nutrition and Physical Activity for 2014-2018. Available at: www.gov.pl/web/zdrowie/ narodowy-program-zdrowia (access: 10.01.2019).

5. Molnár D. The prevalence of the metabolic syndrome and type 2 diabetes mellitus in children and adolescents. Int J Obesity 2004; 28 (suppl 3): 70-74. doi: 10.1038/sj.ijo.0802811

6. Levy-Marchal C, Arslanian S, Cutfield W, et al. Insulin resistance in children: consensus, perspective and future directions. J Clin Endocrinol Metab 2010; 95: 5189-98. doi: 10.1210/jc.2010-1047

7. Skowrońska B, Fichna P, Stankiewicz W. Pre-diabetes and diabetes type 2 - new challenges in pediatrics. Pediatric Rev 2009; 4: 272-276.

8. Jarosz M. Pyramid of Healthy Nutrition for Children and Physical Activity of Children and Adolescents. IZZŻ 2018; 6-7.

9. Cummings JH, Mann JI, Nishida C, Vorster HH. Dietary fibre: an agreed definition. Lancet 2009; 373: 365-366. doi: 10.1016/S01406736(09)60117-3

10. Aravind N, Sissons M, Fellows CM. Optimisation of resistant starch II and III levels in durum wheat pasta to reduce in vitro digestibility while maintaining processing and sensory characteristics. Food Chem 2013; 136: 1100-1109. doi: 10.1016/j.foodchem.2012.08.035

11. Baghurst KI, Baghurdt PA, Record SJ. Dietary fibre, non-starch polysaccharide, and resistant starch intakes in Australia. In: CRC Handbook of Dietary Fibre in Human Health 2001; 583-591.

12. Lockyer S, Nugent AP. Health effects on resistant starch. Nutrition Bulletin 2017; 10-41. https://doi.org/10.1111/nbu.12244

13. Landon S, Colyer CG, Salman H. The resistant starch report, an Australian update on health benefits, measurement and dietary intakes. Food Australia Supplement 2012.

14. Marlatt KL. Role of resistant starch on diabetes risk factors in people with prediabetes: Design, conduct and baseline results of the STARCH trial. Contemp Clin Trials 2018; 65: 99-108. doi: 10.1016/j. cct.2017.12.005

15. Aryana K, Greenway F, Dhurandhar N, et al. A resistant-starch enriched yogurt: fermentability, sensory characteristics, and a pilot study in children. F1000Res 2015; 4: 139. doi: 10.12688/f1000research.6451.1
16. Bodinham CL, Frost GS, Robertson MD. Acute ingestion of resistant starch reduces food intake in healthy adults. Br J Nutr 2010; 103: 917-22. doi: 10.1017/S0007114509992534

17. Poquette NM, Wang Ya-J, Lee SO. Parboiled brown rice product reduces postprandial plasma glucose response in men. J Nutr Food Sci 2012; 2: 1-5.

18. Hallström E, Sestili F, Ladiandra D. A novel wheat variety with with elevated content od amylose increases resistant starch dormation and may beneficially influence glycaemia in healthy subjects. Food Nutr Res 2011; 55. doi: 10.3402/fnr.v55i0.7074

19. Stewart ML. Type-4 resistant starch in substitution for available carbohydrate reduces postprandial glycemic response and hunger in acute, randomized, double-blind, controlled study. Nutrients 2018; 10: 129. doi: 10.3390/nu10020129

20. Kasley MM, Zaepfel AA, Bjornstad P, Nadeau KJ. Age-related consequences of childhood obesity. Gerontology 2014; 60: 222-228. doi: 10.1159/000356023

21. Dibaise J, Zhang H, Crowell MD, et al. Gut microbiotaand its possible relationship with obesity. Mayo Clin Proc 2008; 83: 460-469. doi: $10.4065 / 83.4 .460$

22. Ordiz Ml. The effect of dietary resistant starch type 2 on the microbiota and markers of gut inflammation in rural Malawi children. Microbiome 2015; 3: 37. doi: 10.1186/s40168-015-0102-9

23. Maier TV, Lucio M, Lee LH, et al. Impact of dietary resistant starch on the human gut microbiome, metaproteome, and metabolome. MBio 2017; 8; pii: e01343-17. doi: 10.1128/mBio.01343-17.

24. Lobstein T, Jackson-Leach R, Moodie ML, Hall KD. Child and adolescent obesity: part off a bigger picture. Lancet 2015; 385: 25102520. doi: 10.1016/S0140-6736(14)61746-3

25. Gentile CL, Ward E, Holst JJ, et al. Resistant starch and protein intake enhances fat oxidation and feelings of fullness in lean and overweight/obese women. Nutr J 2015; 14: 113. doi: 10.1186/s12937015-0104-2

26. Sandberg J, Björck I, Nilsson A. Effects of whole grain rye, with and without resistant starch type 2 supplementation, on glucose tolerance, gut hormones, inflammation and appetite regulation in an 11-14.5 hour perspective; a randomized controlled study in healthy subjects. Nutr J 2017; 21: 16-25. doi: 10.1186/s12937-017-0246-5

27. Ble-Castillo JL, Juárez-Rojop IE, Tovilla-Zárate CA, et al. Acute consumption of resistant starch reduces food intake but has no effect on appetite ratings in healthy subjects. Nutrients 2017; 9: 696. doi: 10.3390/nu9070696.

28. Cani PD. Human gut microbiome: hopes, threats and promises. Gut 2018; 67: 1716-1725. doi: 10.1136/gutjnl-2018-316723

29. Harmsen HJ, Goffau MC. The human gut microbiota. Adv Exp Med Biol 2016; 902: 95-108. doi: 10.1007/978-3-319-31248-4_7 